\title{
Specifics in Children's Drawings with Autism
}

\author{
Veronika Ivanova*
}

\author{
Medical University "Prof. Dr. Paraskev Stoyanov", Division de Psiquiatría y Psicología Médica, Varna 9002, \\ Varna Center, ul., "Professor Marin Drinov" 55, Bulgaria
}

\begin{abstract}
Background: The peculiarities of sensory perception and perception of one's own body in children with autism are the basis for understanding their cognitive and social development difficulties.

Objective: The study aims to structure different categories of drawings of children with autism and compare them with the severity of autism measured by CARS2. Methods: 120 children aged 3 to 9 years were studied $(X=6.26, S D=3.16)$. Drawings of autistic children. The children have a white sheet, pencils, a children's drawing table, and the experimenter asks them to draw a person. The children were studied with CARS. 2. Clinical method: includes observation, direct work with the child on each of the topics of the methodology used, interview with parents, diagnostic discussion with the clinical team. Psychodiagnostic method: includes an examination of children with mental developmental stairs, assessment of cognitive, communication, socioemotional and sensorimotor functions. CARS 2 Childhood Autism Rating Scale | Second Edition Statistical.
\end{abstract}

Method: includes data processing using the SPSS programme. Descriptive statistics, correlation analysis, a frequency distribution of data are used for data analysis.

Results: The results show eight main categories of drawings in autistic children: 1. circles, water; 2. patches of colour covering the human figure or representing a human figure without an external boundary; 3 . figures and letters; 4 . human figures fenced as a bubble, a human figure composed of parts of objects (the elements are not connected); 5 . objects with geometric shapes (buildings, roads with markings, apartment blocks, strange shells; 6. road signs, logos.

Conclusions: There is no statistical dependence between the severity of autistic symptomatology and the types of drawings. We can draw some conclusions about how a child with autism perceives his own body from the presented results. Because we see that in mild and moderate degrees of autism CARS 2, the whole variety of drawing categories was evaluated, while in severe and very severe degrees of expression of the disorder circles, colourful spots with vague boundaries predominate. Children with autism often identify with non-living objects, street signs, eccentric houses and towers.

Keywords: Autism, drawings, body image.

\section{INTRODUCTION}

Drawing is an everyday activity that is innate to humans [1-3]. Drawing is indeed a unique experience for the child of representing the self and the world. The diagnosis of autism involves a symptom that has received relatively little research attention: a lack of normal creativity. It has long been known that cognitive and perceptual processing is unusual in autistic individuals [4-6]. In a study by Sheppard [7], autistic children and adolescents had to copy meaningful and nonmeaningful figures (constructed with the same line components) that were either two- or threedimensional. Both autistic and typical groups produced more accurate copies of meaningful figures, compared with nonmeaningful ones, and also of two-dimensional, compared with three-dimensional stimuli. Importantly, however, autistic children were less affected by dimensionality than typical children and more accurately represented projection and perspective for three-dimensional figures. This is consistent with

*Address correspondence to this author at the Medical University "Prof. Dr. Paraskev Stoyanov", Division de Psiquiatría y Psicología Médica, Varna 9002, Varna Center, ul., "Professor Marin Drinov" 55, Bulgaria; Tel: +359895004989; E-mail: veronika_ivanovi@abv.bg another study by Sheppard [7]. Who found that autistic participants were less affected by dimensionality than typical participants when copying line-drawn figures but not real objects. Several studies have tested the accuracy of the theories directly with drawing tasks [8]. Booth found that autistic children were more likely to begin their renditions with local detail. [9]. Drake and Winner's autistic savant artist (a 10-year-old boy of average intelligence) used a local strategy to complete drawings of three-dimensional objects to a greater extent than a comparison group of children with autism but no drawing talent. He also performed particularly well on local perceptual tasks (embedded figures, block design) and poorly on a global task (classification of impossible figures). Some studies report no group differences in drawing speed or accuracy [10-13]. Some studies used two-dimensional figures, while others used three-dimensional figures. The inclusion of dimensionality is a relatively advanced drawing component, especially for children [12-14], which may obscure more subtle indices or variations. In the study by Jaime Craig and Simon Baron-Cohen, children with Autism and Asperger Syndrome (AS) could generate possible novel changes in an object. However, they generated fewer of them compared to 
controls. Using a test of imaginative fluency [15]. Children with autism and AS generated fewer suggestions involving the attribution of vividness to foam shapes than controls instead of generating reality-based suggestions of what the shapes might be. While this indicates executive dysfunction, it does not directly explain why imaginative creativity is more difficult than reality-based creativity $[6,10,16]$.

According to most authors, the maturation of drawing expressiveness is proportional to the maturation of cognitive and emotional functioning [14,17-20]. Research shows that children with Autism Spectrum Disorder (ASD) have lower somatosensory perception than normotypical, age-matched children [21]. Inappropriate drawing of children is a consequence of strong inhibition of socio-relational components. This observation is supported by the fact that even children with ASD who have an adequate intellectual level show delays in drawing $[11,22,27]$.

\section{MATERIALS AND METHODS}

The study sample consisted of 120 children diagnosed with ASD. The study design is crosssectional. Participant description in Table 1: 120 children on the ASD (inclusion criteria are psychiatric diagnosis and score of CARS 2) and aged between 3 and 9 years participated in this study $(M=6.27$ years; $\mathrm{SD}=3.17)$. Of these $(38 \%$ girls $)$, all children were recruited through local community contacts in Bulgaria. Children were provided with a white sheet, pencils, and a children's drawing table, and the experimenter asked them to draw a person. The children were studied with CARS 2 with varying degrees of disability (very severe4 to mild grade 1). Ethics of the study: informed consent with an output number 335 was obtained for the study from the local ethics committee of "Saint Marina Hospital", Bulgaria Varna.

\section{Statistical Method}

Involves data processing using SPSS 19 programme. For data analysis, we use descriptive statistics, correlation analysis, a frequency distribution of data. The dependent variable is the ability and form of drawing, and the independent variable is the degree of autistic disability. CARS 2 helps identify children with autism and determine symptom severity through quantifiable assessments based on direct observation $(X=41.54 \mathrm{SD}=9.17)$. Reliability was measured with a Cronbach Alpha coefficient of 0.87 . Interrater reliability
( $r$ ) for each of the 15 scales based on 120 children ranged from 0.45 to 0.84 with an average of 0.62 .

\section{RESULTS}

Not all children in all groups were able to draw a picture of a man, so we have minimal instruction and give the child the necessary time; they draw at the moment they want. In this research, we have free drawing, and we follow the child and his rhythm. This is necessary because of the peculiarities of autistic children who are easily remembered visually, copying other people's drawings. The purpose of the study is to free expression of creativity in the child and not test his skills to copy or follow an adult's instructions. The study sample consisted of 120 children diagnosed with ASD: 42 on the CARS 2- low level of disorder, 54- medium level of disorder, 18- high level of disorder and only 6 with very severe level. The characteristics of the sample according to age and gender are shown in Table 1:

Table 1: Characteristics of the Sample: Descriptive Statistics

\begin{tabular}{|c|c|c|c|}
\hline & $\mathbf{N}$ & Mean & Std. Deviation \\
\hline \hline Age & 120 & 6.27 & 3.17 \\
\hline Sex & 120 & 1.30 & 0.46 \\
\hline
\end{tabular}

Provided in Figure 1 is descriptive statistics on the severity of autistic symptoms obtained in CARS 2( CARS 15- summary):

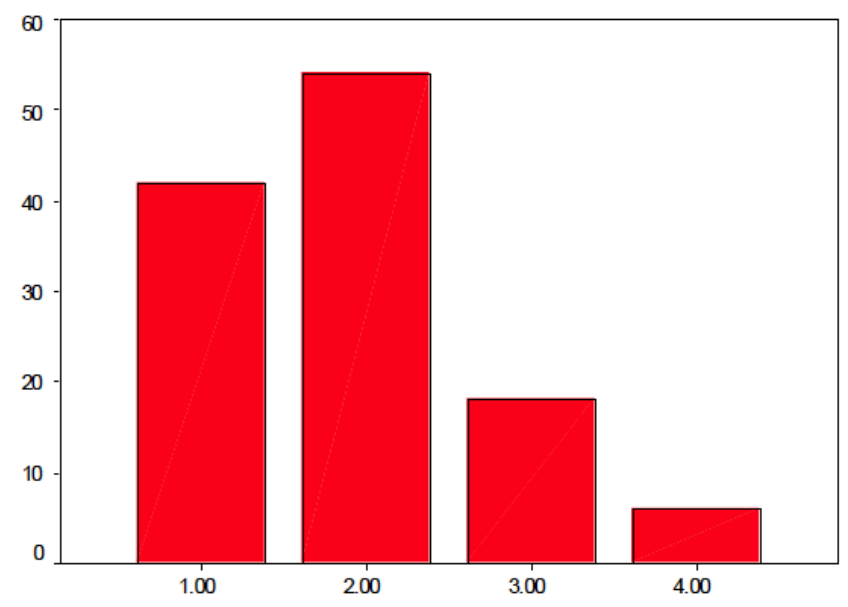

Figure 1: 1-mild degree, 2-moderate degree, 3- severe,4very heavy.

Children's drawings are structured and analysed in several categories presented in Figure 2: 


\section{Categories}

1. Embryonal-circles, water, amoeba

2. Color spots that cover the human figure or depict a human figure without external borders

3. Figures and letters

4. Human figures fenced as a bubble, a human figure composed with parts of objects body parts (the elements are not connected)

5. Geometric shapes objects (buildings, streets with marking, residential blocks, strange shells

6. Road signs, logos

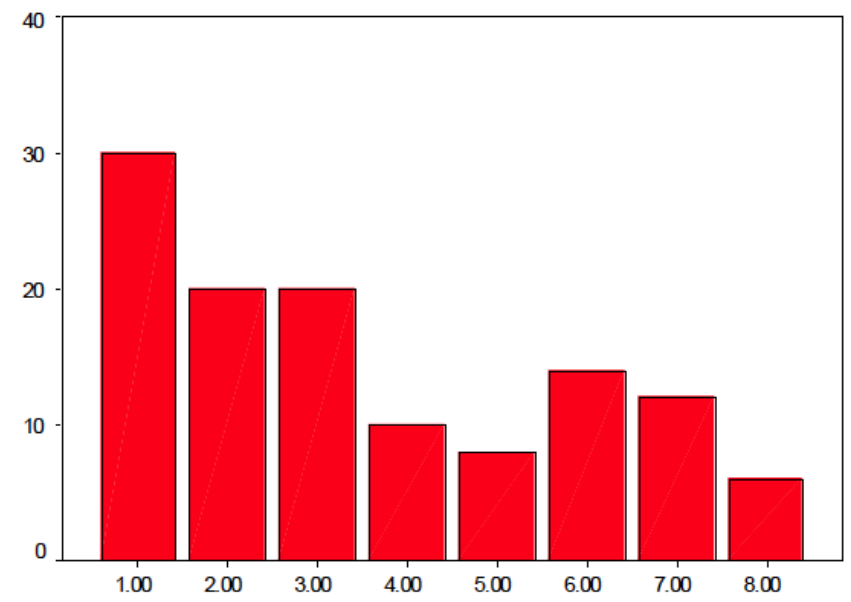

Figure 2:

The analysis of the frequency shows that we have the most drawings in the first category (circles, embryonic, water) followed by second and third cloisters, namely colourful spots, numbers, and letters. At least the drawings of whole human figures, in parts in which the elements are or are not connected between themselves or replaced by an unfair subject.

Correlation analysis is used to know the relationship between the severity of symptoms and types of drawings. In our case, it was negative $(-0.193)$, which means there is no or even retreated between the weight of autistic symptoms and the types of drawings that children draw. Correlation between the intellectual level is negative to $(-0.186)$, there is a positive correlation between the communication scale of CARS 2 and the types of drawings, (0.56).

The results show that the light and a moderate degree of disorder meet all kinds of drawings, except for category 5 drawings found only in children with a moderate degree of autistic disorder. In those with a severe and very severe degree, embryonic drawings and circles, water, colour spots and isolated by some other categories are predominant.

Interestingly, children in the worst end of the disorder prefer to draw colourful spots, one particular type of drawing dominates, while children in the lighter forms show a sum of all types of categories. Only in ten of all drawings there is a painted human figure, often with non-living elements.

\section{DISCUSSION}

As might predicted from the clinical literature, a general impairment in creativity has found in children with ASD and AS. Children with autism simply produce fewer novel responses compared to controls. The results confirmed that the children with autism and

AS showed less imaginative creativity. The general tendency of children in these two clinical groups was to

Table 2: Presents the Distribution of Types of Drawings, According to the Categories of Autistic Symptoms

\begin{tabular}{|c|c|c|c|c|c|}
\hline Picture category & Cars 1 level & Cars 2 level & Cars 3 level & Cars 4 level & Total \\
\hline 1 & 4 & 16 & 8 & 2 & 30 \\
\hline 2 & 8 & 6 & 6 & & 20 \\
\hline 3 & 10 & 6 & 2 & 2 & 20 \\
\hline 4 & 6 & 4 & & & 10 \\
\hline 5 & 2 & 6 & & & 8 \\
\hline 6 & 6 & 4 & 2 & 2 & 14 \\
\hline 7 & 4 & 8 & & & 12 \\
\hline 8 & 2 & 4 & & & 6 \\
\hline Total & 42 & 54 & 18 & 6 & 120 \\
\hline
\end{tabular}


produce responses that were 'real' inanimate things to which the shapes were very similar $[16,23]$. In their study, Craig and Baron-Cohen [15] found deficits in children with autism and AS. The results supported both hypotheses, finding that children with autism and AS could produce possible novel changes to an object, but they produced fewer such novel changes overall. Children with autism and AS showed less fluid imagination overall and generated fewer suggestions on measures of imaginative ability. In particular, they were less likely to fluidly match foam shapes than the control group and instead generated reality-based suggestions of what the shapes might be. Thus, although there is some evidence of executive dysfunction, this does not necessarily explain the additional difficulties they showed in imaginative creativity. These patterns were seen in both the children with Asperger Syndrome (AS) and the children with autism [6].

From the results of this study, it is apparent how often the unconscious body image in autistic children is associated with non-living objects and is largely partial, disjointed. In the drawings in which a human figure appears, it is surrounded in a "protected circle", which is associatively reminiscent of the womb and could be an expression of the need for safety and security, which is recognised as a basic need in psychosis patients and a part of autistic children. Another large group are the impressionism style drawings where images and figures blur; there are no clear boundaries between me and others. Melzer [8] and collaborators describe their observations of lack of a clear distinction between "inside and outside", between real, symbolic and imaginary Lakan in children with autism [14,24].

Several studies $[10,19,25,26,29]$ described the production of kinetic drawings in children with autism and their tendency to produce an image with almost incomprehensible diagrammatic symbolism - a composition of schematic fragments. The authors describe improved results in interactive techniques with autistic and mentally disabled children [16], where the development of the child's visual skills and nonverbal communication is achieved through parallel drawing. The discussion and interpretation of the visual results are mainly made through the means of the visual activity itself to achieve a shared creative space between the therapist and the child. It is known that children with autism show a good ability to distinguish specific information (size, colour, shape) and a weak ability to determine the symbolic relationships between this information $[19,24]$. However, it is difficult not to look for symbolic meaning in some of these drawings, such as the pictures of a scratched face, which are a metaphor for the suffering of these children.

In one study, Ebrahimi compared the effect of drawing and storytelling on sleep quality in children with autism. According to the results, she recommended that more interventions should be implemented, especially the use of painting and storytelling in children with autism because it is inexpensive, effective, and practical in treating sleep disorders $[28,30,31]$.

Magda Di Renzo examines the correlation between drawing ability and the level of development in autistic children [32]. Drawing level was observed in spontaneous production by creating a scale ranging from the presence of disordered scribbling to the presence of body schema. The results showed a significant correlation between drawing production and the Social-Affection component; drawing is strongly influenced by emotional as well as intellectual inhibition. The relationship between drawing and chronological age and the difference made between drawings made in the assessment context and those made during the therapeutic process is also highlighted through some drawings.

From the results, it appears that there is no statistical dependence between the severity of autistic symptomatology and the type of drawings. Children with autism are significantly less likely than other children to draw whole human figures when they are in pieces, i.e., the parts are not connected, or one of the parts is an object. Based on the hypothesis of psychoanalysts who study children with autism, we can assume that the lack of integrity in the conception of their own body presents a body in need of protection of embryonic drawing a circle of water that is enveloped [33]. Children's drawings depend on what they mean, not what they see in front of them. In clinical work with autistic children, it is typical that even if they are verbal, they do not name their drawings and have little enthusiasm for imaginary engagement with their work. In the children's drawings, we can assume the image of the self and the perception of the body image. Daniel Stern places the sense of the emerging self and the sense of the other at the heart of early childhood experiences [34]. In children's drawings, we can assume the image of the self and perceive the image of the body. Daniel Stern places the sense of the emerging self and the sense of the other at the centre of early childhood experiences [35]. 
In observing and evaluating the drawings of autistic children, Di Renzo M [32] notes that many of them do not use drawing in a communicative and relational way but in a stereotypical way to escape context. When comparing drawings of the same child in different contexts, they found that children often differed significantly. In the study of we observed that children in our sample have difficulty in their drawing ability that increases with symptom severity Di Renzo M. observed that children have difficulty in their drawing ability that increases with symptom severity and that none of them has unique abilities. The development of drawing supports the concept of a pervasive disorder by noting that the lack of communication affects not only the verbal level but all channels of expression and imaginative processes, as is also evident in the poverty or lack of symbolic play. The results show the close relationship of drawing with the level of autistic symptomatology. All children who are part of ASD have a significant delay in the drawing process, and this delay is not related to the $I Q$ but rather to social affection [32]. In our research, we found that there is no strong correlation between IQ level and the ability of drawing.

\section{CONCLUSION}

In summary, we can say that the results show that the relationship of drawing with the level of autistic symptomatology is not related to the IQ but rather to sociability and the level of contact. The results show that there is no statistical dependence between the severity of autistic symptomatology and the types of drawing. In conclusion, we can say that the delay in drawing development supports the concept of a pervasive disorder. And lack of communication does not only affect the verbal level but all expressive channels and imaginative processes, as it is also evident from the poverty or lack of symbolic play.

Future research needs to utilise the usefulness and desirability of using the drawing tool in both observational and therapy contexts. It will be interesting to examine the relationship between the therapeutic contact and the sign tube. It is likely that as the therapeutic sense and parent-child relationship improve, there will also be a change in the children's drawing. There is a need to combine studies such as this with studies using longitudinal designs that track the development of the same child over time.

\section{ACKNOWLEDGEMENT}

I thank the whole team of the children's and adolescent clinic of psychiatry, as well as my colleagues from the Department of Psychiatry and Medical Psychology, for the support of my longstanding clinical and research projects.

\section{REFERENCES}

[1] Ebrahimi HK, Esmaeilian S, Jafarnejad S, Sohrabi S, Papi S A Comparative Study the Effect of Painting and Storytelling on Children's Sleep with Autism. Ann Roman Soc Cell Biol 2021; 398-408. Retrieved from https://www.annalsofrscb.ro/ index.php/journal/article/view/1516

[2] La Femina F, Senese VP, Grossi D, Venuti P. A battery for the assessment of visuospatial abilities involved in drawing tasks. Clin Neuropsychol 2009; 23(4): 691-714. https://doi.org/10.1080/13854040802572426

[3] Mottron L, Dawson M, Soulieres I, Hubert B, Burack J. Enhanced perceptual functioning in autism: An update, and eight principles of autistic perception. Jf Aut Dev Disord 2006; 36(1): 27-43.

https://doi.org/10.1007/s10803-005-0040-7

[4] Bruno B. The Empty Fortress: Infantile Autism and the Birth of the Self, The Free Press, New York 1967.

[5] Dubovski and Evans. Otvad dumite.Artterapiq $s$ deza ot autistichniq spektar. Zentar za psihosozialna podkrepa. Sofiq 2014. ISBN 9786197037074

[6] Huri M, Şahin S, Kayıhan H. Investigation of hand function among children diagnosed with autism spectrum disorder with upper extremity trauma history. Ulus Travma Acil Cerrahi Derg 2016; 22: 559-565.

https://doi.org/10.5505/tites.2016.58712

[7] Sheppard E, Ropar D, Mitchell P. Perceiving the impossible. How individuals with autism copy paradoxical figures. Autism 2009; 13: 435-452. https://doi.org/10.1177/1362361309105661

[8] Melzer. Autism research. Ed. Center for Psychosocial Support, 2019 Reprinted in Kanner L (1968). "Autistic disturbances of affective contact". Acta Paedopsychiatrica 2019; 35 (4): 100-36.

[9] Booth R, Charlton R, Hughes C, Happé F. Disentangling weak coherence and executive dysfunction: Planning drawing in autism and attention-deficit/hyperactivity disorder. Philosophical Transactions of the Royal Society B: Biological Sciences 2003; 358: 387-392 https://doi.org/10.1098/rstb.2002.1204

[10] Eames K, Cox MV. Visual realism in the drawings of autistic Down's syndrome and normal children. $\mathrm{Br} \mathrm{J}$ Dev Psychol 1994; 12: 235-239. https://doi.org/10.1111/j.2044-835X.1994.tb00630.x

[11] Frith U. Autism: Explaining the Enigma. Oxford: Basil Blackwell 1989/1991.

[12] Lachman-Chapin M. Making Verbal the Nonverbal: A Commentary. Art Ther 1983; 1(1): 47-49. https://doi.org/10.1080/07421656.1983.10758737

[13] Tendlarz S. De qué sufren los niños? La psicosis en la infancia; Lugar editorial Buenos Aires, 1996.

[14] Yankelevech $\mathrm{H}$. Ensayos sobre autismo y psicosisKliné. Bs. As. 1998; ISBN 987-9154-08-8 Pág. 120

[15] Baron-Cohen S. Theory of mind in normal development and autism. Price 2001; 31: 174-183.

[16] Jolliffe T, Baron-Cohen S. Are people with autism and Asperger syndrome faster than normal on the Embedded Figures Test? J Child Psychol Psych 1997; 38: 527-534. https://doi.org/10.1111/j.1469-7610.1997.tb01539.x

[17] Cannoni E. Lo sviluppo del disegno [The drawing development]. Carocci, Roma 2005. 
[18] Crocetti G. I disegni dei bambini. Metafore e simboli del benessere bambino [The drawings of children. Metaphors and symbols of child welfare]. Armando Editore, Roma 2008.

[19] Lakan J. Family complexes. Ciela. Sofiq 2008.

[20] Luquet G. Children's drawings. Free Association Books, London 2001.

[21] Dubovski and Evans. Otvad dumite.Artterapiq s deza ot autistichniq spektar. Zentar za psihosozialna podkrepa. Sofiq 2014; ISBN 9786197037074

[22] Pizzo Russo L. II disegno infantile. Storia, teoria, pratiche. Aesthetica, Palermo 2015.

[23] Mottron L, Dawson M, Soulieres I, Hubert B, Burack J. Enhanced perceptual functioning in autism: An update, and eight principles of autistic perception. J Aut Dev Disord 2006; 36(1): $27-43$ https://doi.org/10.1007/s10803-005-0040-7

[24] Romanczyk RG, Ekdahl M, Lockshin SB. Perspectives on research in autism: Current trends and future directions. In D. E. Berkel (Ed.), Autism: Identification, education, and treatment. Hillsdale, NJ: Erlbaum 1992; pp. 21-51.

[25] Huri M, Mehr BK, altuntaş O, Kayiha H. Yaygın gelişimsel bozukluğu olan ve normal gelişim gösteren çocukların taktil tercihlerinin karşılaştırılması. Ergoterapi ve Rehabilitasyon Dergisi 2014; 2: 21-28.

[26] Frith U, Happé F. Autism: Beyond "theory of mind" Cognition 1994; 50(1): 115-132. https://doi.org/10.1016/0010-0277(94)90024-8

[27] Olivero Ferraris A. II significato del disegno infantile. Bollati Boringheri, Torino 2012.
[28] Romanczyk RG, Ekdahl M, Lockshin SB. Perspectives on research in autism: Current trends and future directions. In D. E. Berkell (Ed.), Autism: Identification, education, and treatment. Hillsdale, NJ: Erlbaum 1992; pp. 21-51.

[29] Ropar D, Mitchell P. Susceptibility to illusions and performance on visuospatial tasks in individuals with autism. J Child Psychol Psychiat 2001; 42: 539-549. https://doi.org/10.1111/1469-7610.00748

[30] Di Renzo M, Marini C, Bianchi di Castelbianco F. II processo grafico del bambino autistico [The drawing process of the autistic child]; Magi, Roma 2013.

[31] Olivero Ferraris A. II significato del disegno infantile. Bollati Boringheri, Torino 2012.

[32] Di Renzo M, Marini C, di Castelbianco FB, Racinaro L, Rea M. Correlations between the Drawing Process in Autistic Children and Developmental Indexes. J Psychol Psychother 2017; 07(02). https://doi.org/10.4172/2161-0487.1000291

[33] Basso M. Una aproximación psicoanalítica al Autismo. Ed. Letra Viva, Buenos Aires 2013; p. 24.

[34] Craig J, Baron-Cohen S. Creativity and Imagination in Autism and Asperger Syndrome. J Autism Dev Disord 1999; 29: 319-326. https://doi.org/10.1023/A:1022163403479

[35] Willats J. How children learn to draw realistic pictures. Quart J Exp Psychol 1977; 29: 367-382. https://doi.org/10.1080/14640747708400614

https://doi.org/10.6000/2292-2598.2021.09.04.3

(c) 2021 Veronika Ivanova; Licensee Lifescience Global.

This is an open access article licensed under the terms of the Creative Commons Attribution Non-Commercial License (http://creativecommons.org/licenses/by-nc/3.0/) which permits unrestricted, non-commercial use, distribution and reproduction in any medium, provided the work is properly cited. 